\title{
The influence of habitat conditions on the abundance and selected traits of the rare medicinal plant species Filipendula vulgaris Moench
}

\author{
${ }^{1}$ Kinga Kostrakiewicz-Gieraltt, ${ }^{2}$ Alina Stachurska-Swakoń
}

Department of Plant Ecology, Institute of Botany, Jagiellonian University, 'Lubicz 46, 31-512 Kraków, Poland, "e-mail: kinga.kostrakiewicz@uj.edu.pl

${ }^{2}$ Kopernika 27, 31-512 Kraków, Poland.

Received: 21 April 2017/Accepted: 05 June 2017

\begin{abstract}
The research on the influence of habitat conditions on the traits of Filipendula vulgaris were carried out in 2015 and 2016 in abandoned wet meadows (Patches I and II) and frequently disturbed, calcareous grasslands (Patches III and IV). The cover of vascular plants and cryptogams was much greater and soil $\mathrm{pH}$ was remarkably lower in the meadow patches than in the grassland ones, whereas the height of neighbouring plants and soil humidity gradually decreased from Patches I to IV. The meadow populations of F. vulgaris showed much lower abundance as well as lower total relative abundance of seedlings and vegetative rosettes compared to the grassland populations due to the scarcity of safe sites for offspring recruitment. Rosettes presenting solely spatial variability were characterised by a significantly greater number of short leaves in the meadow populations or not numerous, large leaves in the grassland populations. The similar (in consecutive years) height of generative shoots, the number of cauline leaves, inflorescences and flowers gradually decreased at subsequent study sites. The results may provide the basis for further studies on the impact of habitat conditions and the size of aboveground parts of F. vulgaris on the content of bioactive compounds in plant material.
\end{abstract}

Key words: calcareous grassland, disturbances, individual and population traits, land abandonment, Molinia meadow, soil conditions.

\section{Introduction}

The investigations focusing on abundance and structure of populations, as well as individual traits of medicinal plants, are very important ones. To date, the raw materials were harvested from wild growing plants, therefore the aforementioned studies enabled choosing of the source of the best quality plant material. Moving forward, the results of the observations might provide a basis for successful cultivation of this species for practical purposes. Currently, numerous authors have investigated the population and individual traits of species used in official and folk medicine. Such observations were devoted to numerous annuals (Zając et al., 2011), perennials (Kahmen \& Poschlod, 2000; Morozowska, 2000; Hegland et al., 2001; KostrakiewiczGierałt, 2015a ), as well as shrubs and trees (Barna, 2004; Hampe, 2005).
One of these medicinal plants is Filipendula vulgaris Moench, which reveals antibacterial, anti-inflammatory, antipyretic, antihyperalgesic (Pavlovic et al., 2007; Katanic et al., 2015; Samardžić et al. 2016) and antioxidant properties (Maksimović et al. 2007, Katanic et al., 2015), as well as nootropic activity (Shilova \& Suslov, 2015; Shilova et al., 2015). To date, studies focusing on the variability of selected traits of individuals of Filipendula vulgaris in cultivation (Lempiäinen, 1978; Bączek et al., 2010; Capecka et al., 2012), as well as in natural localities (Lempiäinen, 1982), are scarce. Regarding the widespread use of the aboveground parts of dropwort as medicinal material, the main goal of the investigations was to assess the effect of habitat conditions on population abundance and selected traits of Filipendula vulgaris Moench in abandoned meadows and in frequently disturbed calcareous grasslands. 


\section{Material and methods}

\subsection{The studied species}

Filipendula vulgaris Moench (syn. F. hexapetala Gilib., Rosaceae), commonly known as dropwort, is a rosetteforming perennial, clonal herb with short rhizomes and roots bearing tubers (Klimešová \& Klimeš, 2006). The flowering shoots, up to $80 \mathrm{~cm}$ high, bear inflorescences consisting of many cream-white flowers, pollinated mainly by insects (Clapham et al., 1987) or wind (Weidema et al., 2000). Filipendula vulgaris belongs to euro-siberian species (Zając \& Zając, 2009), growing in the wild, from and north-western Africa, through Europe to middle Asia. F. vulgaris is a diagnostic species for FestucoBrometea class, where calcareous grasslands are included (Medwecka-Kornaś et al., 1966; Towpasz \& StachurskaSwakon, 2011, 2012). However, the species can also occur in wet meadows from the Molinietalia order (Dubiel et al., 1999) and Caricetalia davalianae order (Towpasz \& Stachurska-Swakoń, 2009).

Dropwort is listed in the European Red List of Medicinal Plants (Allen et al., 2014), as well as in many national Red Books and Lists (Curtis \& McGough, 1988; Moser et al., 2002; Cheffings \& Farrell, 2005; Stroh et al., 2014).

\subsection{The study area}

The investigations were carried out in the south-western part of Kraków (southern Poland) from Pychowice (N 50'1'26"; E 1952'25") to Tyniec (N 50¹'26"; E 19 50'1"), at ca. $210 \mathrm{~m}$ a.s.l., on the low flood terrace of the Vistula river where the limestone hills (JurassicCretaceous) and tectonic depressions of the Brama Krakowska gate occur (Kondracki, 2000). The observations were conducted in meadows and calcareous grasslands surrounded by arable fields and ruderal plant communities occurring in the vicinity of roads and housing estates. Patches I and II represented abandoned, overgrowing wet meadows from the Molinion caeruleae alliance, characterised by the presence of Dianthus superbus, Galium boreale, G. verum, Gladiolus imbricatus, Inula salicina, Iris sibirica, Lotus corniculatus, Selinum carvifolia, as well as Succisa pratensis. In Patch I, measuring $700 \mathrm{~m}^{2}$, shrubs such as Salix cinerea, S.repens spp. rosmarinifolia, as well as tall-growing perennials such as Betonica officinalis and Serratula tinctoria dominated. Patch II, measuring $800 \mathrm{~m}^{2}$, was overgrown by tall-growing perennials Sanguisorba officinalis, Serratula tinctoria, and Solidago canadensis, as well as S. serotina. Patches III and IV were located on south-exposed moderate slopes and represented frequently visited and trampled calcareous, grasslands from the Festucetalia valesiacae order. They were characterised by the presence of Anthericum liliago, Dianthus carthusianorum,
Festuca rupicola, Plantago media, Scabiosa ochroleuca, Salvia nemorosa, S. verticillata and Thymus sp. Patch III, measuring $600 \mathrm{~m}^{2}$, was dominated by Anthericum liliago, Euphorbia cyparisias and Salvia verticillata. Patch IV, measuring $800 \mathrm{~m}^{2}$, was dominated by Dianthus carthusianorum, Festuca rupicola, Inula ensifolia and Thymus sp.

\subsection{The investigation of the habitat conditions}

In all of the Patches one representative, permanent study plot (15 m x $15 \mathrm{~m}$ ) was established and fenced. Within each plot, 20 measuring points were chosen and marked with plastic pegs. Four points were placed systematically in the corners of the permanent plots, while the remaining points were chosen randomly. The marked points served as centres for setting iron rims, $30 \mathrm{~cm}$ in diameter, used for the evaluation of biotic (plant and cryptogam cover, height of vascular plants) and abiotic habitat conditions (moisture and $\mathrm{pH}$ of the soil). The plant and cryptogam cover was measured as a percentage of ground surface covered by vascular plants and cryptogams (moss and lichens). The average height of neighbouring plants was received on the basis of measurements of length (from soil level to the top) of the lowest and highest stems (excluding Filipendula vulgaris) growing within the rim, using a folding tape measure. Soil humidity and $\mathrm{pH}$ value was measured using a BIOWIN soil sensor (range 1-10) in the $5 \mathrm{~cm}$ deep upper soil layer. Soil humidity range: 1-3 - dry, 4-7 - moist, 8-10 - wet; $\mathrm{pH}$ range: 1-6 - acid, 7-10 - alkaline. The survey of the habitat conditions was performed on 8 July 2015 and 10 July 2016.

\subsection{The investigation of rosette traits of Filipendula vulgaris Moench}

In 2015, the abundance of populations of Filipendula vulgaris, understood as total number of adult vegetative leaf rosettes and leaf rosettes with at least one flowering shoot within the Patches, were studied. In the years 2015 and 2016, the number of seedlings, adult vegetative leaf rosettes, as well as leaf rosettes with flowering shoot (shoots) were inventoried and labelled with plastic pegs in the permanent plots. In all rosettes, the number of leaves and length of the longest leaf were noted. Also, the number of flowering shoots and their height (from ground level to basis of inflorescence) were examined in each rosette creating generative stems. Moreover, in all generative shoots, the following traits were counted or measured: (i) the number of cauline leaves (ii) the number of inflorescences; and (iii) the number of flowers per each inflorescence.

\subsection{Statistical analyses}

The normal distribution of each group of the untransformed data (from a particular Patch and year) was tested 
using the Kolmogorov-Smirnov test, while homogeneity of variance was tested using the Levene test at the significance level of $\mathrm{P}<0.05$. As the values in some groups were not consistent with normal distribution, and the variance was not homogeneous, the Kruskal-Wallis H test was applied to check whether there are the significant differences among the Patches in: (i) plant and cryptogam cover, height of standing vegetation, soil humidity and soil pH; (ii) number and length of rosette leaves; and (iii) the number and traits of the flowering shoots. After a significant value of test $(\mathrm{P} \leq 0.05)$, the post-hoc multiple comparisons were performed. Simultaneously, the Mann-Whitney U test was applied to check if there were significant differences in the aforementioned traits between the years. These analyses were performed using the STATISTICA 12 software package. The interactive chi square test calculator (Preacher, 2001) was applied to check whether there were significant differences among the studied Patches and years regarding the share of seedlings, as well as adult vegetative rosettes, and rosettes with flowering shoot (shoots).

\section{Results and discussion}

\subsection{Habitat conditions}

Our results showed that plant and cryptogams cover, height of neighbouring plants, as well as soil $\mathrm{pH}$ and humidity, similar in consecutive years, varied remarkably among

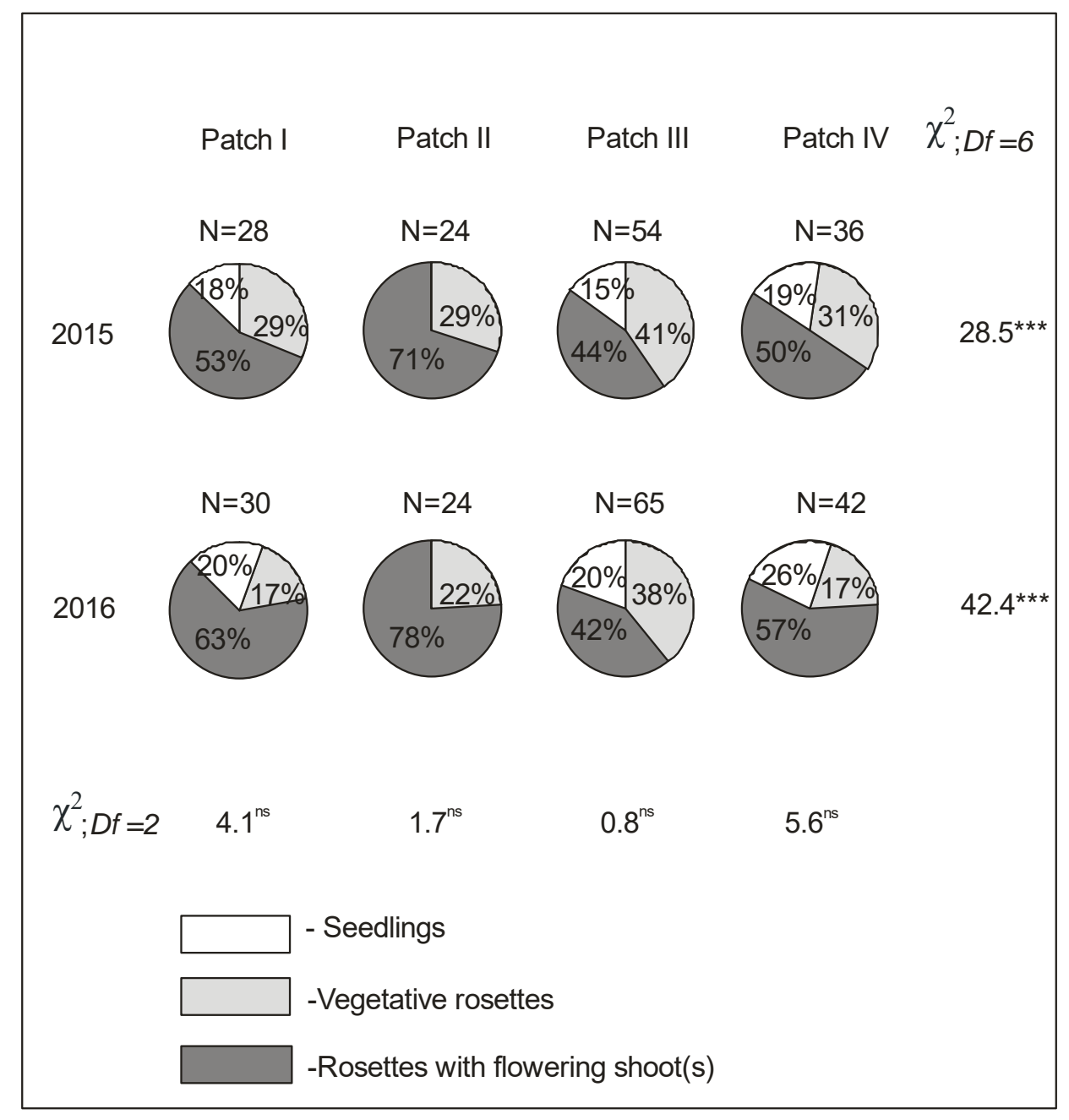

Figure 1. The share of seedlings, vegetative rosettes and rosettes with flowering shoot(s) of Filipendula vulgaris Moench in study plots established in meadows (Patch I and II) and calcareous grasslands (Patch III and IV) in the years 2015 and 2016. Explanations: ns- not significant, *- significant at the level $\leq 0.05 ; * * *$ - significant at the level $\mathrm{P}<0.001$ 
the Patches (the differences were repetitive in consecutive years).

The much lower plant and cryptogam cover observed in Patches III and IV (located in calcareous grasslands) than in Patches I and II (located in meadows) (Table 1) might be caused by loss of seeds deposited in the upper parts of soil as the result of water flowing down the steep slopes during seasonal precipitation. The susceptibility of the seeds to removal with running water was observed both by García-Fayos et al. (2010) and Jiao et al. (2013). On the other hand, many studies (García-Fayos et al., 1995; Cerdà \& García-Fayos, 1997; García-Fayos et al., 2000) proved that seed losses are negligible and the scarcity of vegetation on the slopes might be the result of the limited germination of propagules, as well as difficulties in recruitment and survival of seedlings of numerous species in the shallow, dry and rocky ground. The germination and survival of seedlings could be also reduced by the allelopathic influence of plants growing in the neighbourhood (e.g. Skrzypek et al., 2015). Moreover, the observed gaps in continuous plant cover within the calcareous grassland Patches might be the effect of standing vegetation damage caused by trampling. Such a phenomenon was observed in a wide range of habitats from sand grasslands (Hesp et al.,

Table 1. The mean (range) height of neighboring plants, plant and cryptogam cover, soil humidity and pH in in study plots established in overgrowing meadows (Patch I and II) and grasslands (Patch III and IV) in consecutive the years 2015 and 2016 calculated on the basis of 20 measurements. Explanations: $\mathrm{P} *_{-}$-value $\mathrm{P}$ calculated using the Kruskal-Wallis $\mathrm{H}$ test, $\mathrm{P} * *$ - value $\mathrm{P}$ calculated using the Mann-Whitney $\mathrm{U}$ test. The significant $\mathrm{P}$ values are underlined. The different letters in superscript mean statistically significant difference among Patches

\begin{tabular}{|c|c|c|c|c|c|c|}
\hline \multirow{5}{*}{ 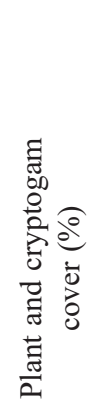 } & & \multicolumn{4}{|c|}{ Patch } & \multirow{2}{*}{$\mathbf{P}^{*}$} \\
\hline & & I & II & III & IV & \\
\hline & 2015 & $98.7(95-100)^{\mathrm{a}}$ & $97.7(90-100)^{\mathrm{a}}$ & $77.8(55-95)^{\mathrm{b}}$ & $91.7(80-100)^{\mathrm{c}}$ & $\underline{0.00001}$ \\
\hline & 2016 & $99.0(98-100)^{\mathrm{a}}$ & $98.6(90-100)^{\mathrm{a}}$ & $80.3(60-100)^{\mathrm{b}}$ & $92.6(80-100)^{b}$ & $\underline{0.00001}$ \\
\hline & $\mathrm{P} * *$ & 0.22 & 0.24 & 0.15 & 0.53 & \\
\hline \multirow{3}{*}{ 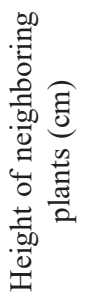 } & 2015 & $44.8(21-73)^{\mathrm{a}}$ & $39.8(17-69)^{\mathrm{ab}}$ & $28.1(7-64)^{b}$ & $26.5(7-45)^{\mathrm{c}}$ & $\underline{0.004}$ \\
\hline & 2016 & $49.4(17-87)^{\mathrm{a}}$ & $40.8(12-77)^{\mathrm{ab}}$ & $32.7(15-70)^{\mathrm{ab}}$ & $23.9(6-47)^{b}$ & $\underline{0.004}$ \\
\hline & $\mathrm{P} * *$ & 0.55 & 0.68 & 0.14 & 0.06 & \\
\hline \multirow{3}{*}{ 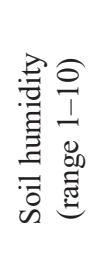 } & 2015 & $8.2(7-10)^{\mathrm{a}}$ & $6.8(4-8)^{\mathrm{ab}}$ & $3.2(2-5)^{b}$ & $2.6(2-4)^{\mathrm{c}}$ & $\underline{0.00003}$ \\
\hline & 2016 & $8.5(7-10)^{\mathrm{a}}$ & $7.2(4-9)^{\mathrm{a}}$ & $5.0(3-4)^{\mathrm{ab}}$ & $3.1(2-4)^{b}$ & $\underline{0.00002}$ \\
\hline & $\mathrm{P} * *$ & 0.63 & 0.35 & 0.24 & 0.06 & \\
\hline \multirow{3}{*}{ 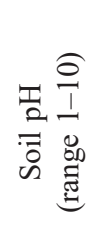 } & 2015 & $6.4(6-8)^{a}$ & $7.0(6-8)^{\mathrm{a}}$ & $7.7(6-9)^{b}$ & $7.8(7-9)^{b}$ & $\underline{0.0001}$ \\
\hline & 2016 & $6.7(6-8)^{\mathrm{ab}}$ & $7.0(6-8)^{\mathrm{a}}$ & $7.6(6-9)^{\mathrm{ab}}$ & $7.9(7-9)^{b}$ & $\underline{0.001}$ \\
\hline & $\mathrm{P} * *$ & 0.45 & 0.80 & 0.93 & 0.87 & \\
\hline
\end{tabular}

Soil humidity range: 1-3-dry, 4-7-moist, 8-10 wet; $\mathrm{pH}$ range: 1-6-acid, 7-10 alkaline. 
2010), through limestone lowland grasslands (Harrison, 1981), to alpine grasslands (Pickering \& Growcock, 2009).

The soil $\mathrm{pH}$ values in the grassland Patches exceeded those noted in the meadow Patches (Table 1). The observed lower values of $\mathrm{pH}$ in the meadows corresponds with data found in Molinia meadows by Zelnik \& Čarni (2008). It might be caused by the formation of carbonic acid and weak organic acids as an effect of decomposition of litter and soil organic matter. Nevertheless, the experiments of Van Duren et al. (1998) produced evidence that artificial sod cut in Molinia meadows contributes to the slight increase of soil $\mathrm{pH}$. Moreover, the reduction of $\mathrm{pH}$ value in the observed meadow Patches might be caused by the runoff of acidifying fertilisers containing ammonium from adjacent arable fields. The mechanisms and effect of fertiliser application on soil acidification has already been widely discussed (Barak et al., 1997; Guo et al. 2010; Goulding, 2016).
The performed observations showed that the height of neighbours of $F$. vulgaris and soil humidity diminished gradually in subsequent Patches (Table 1). Also, other authors found that the augmentation of standing vegetation height causes an increase in soil humidity in wet meadows (Kulik, 2014) and calcareous grasslands (Gross et al., 2008). The aforementioned authors argued that the increased canopy height, accompanied by a growing accumulation of litter, can reduce incident radiation and might promote water retention.

\subsection{The population abundance and traits of rosettes of Filipendula vulgaris Moench}

The performed observations showed that the abundance of rosettes of Filipendula vulgaris varied in subsequent Patches and achieved 82, 94, 176 and 167, respectively. Also, the abundance of seedlings and adult rosettes in the

Table 2. The mean (range) number of leaves per rosette (A) and length (cm) of the longest rosette leaf (B) in vegetative rosettes and rosettes with flowering shoots of Filipendula vulgaris Moench in study plots established in meadows (Patch I and II) and calcareous grasslands (Patch III and IV) in the years 2015 and 2016. Explanations: N- number of data per group; P*- value $\mathrm{P}$ calculated using the Kruskal-Wallis $\mathrm{H}$ test, $\mathrm{P} *_{-}^{*}$ value $\mathrm{P}$ calculated using the Mann-Whitney $\mathrm{U}$ test. The significant $\mathrm{P}$ values are underlined

\begin{tabular}{|c|c|c|c|c|c|c|c|}
\hline \multirow{8}{*}{ 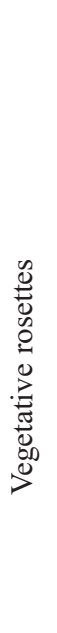 } & & & \multicolumn{4}{|c|}{ Patch } & \multirow{2}{*}{$\mathbf{P} *$} \\
\hline & & \multirow[b]{2}{*}{2015} & I & II & III & IV & \\
\hline & & & $\begin{array}{c}5.0(3-6) \\
\mathrm{N}=14\end{array}$ & $\begin{array}{c}5.3(4-6) \\
\mathrm{N}=14\end{array}$ & $\begin{array}{c}4.0(2-13) \\
\mathrm{N}=27\end{array}$ & $\begin{array}{c}3.1(2-4) \\
\mathrm{N}=17\end{array}$ & 0.06 \\
\hline & & 2016 & $\begin{array}{c}5.3(5-6)^{\mathrm{a}} \\
\quad \mathrm{N}=13\end{array}$ & $\begin{array}{l}5.7(5-7)^{\mathrm{ab}} \\
\quad \mathrm{N}=13\end{array}$ & $\begin{array}{c}3.7(2-10)^{\mathrm{ab}} \\
\quad \mathrm{N}=30\end{array}$ & $\begin{array}{c}2.8(2-4)^{b} \\
\quad N=15\end{array}$ & \multirow[t]{2}{*}{$\underline{0.03}$} \\
\hline & & $\mathrm{P} * *$ & 0.93 & 0.85 & 0.51 & 0.56 & \\
\hline & A & 2015 & $\begin{array}{c}18.0(15-21) \\
\mathrm{N}=14\end{array}$ & $\begin{array}{c}24.3(19-29) \\
\mathrm{N}=14\end{array}$ & $\begin{array}{c}38.0(28-47) \\
\mathrm{N}=27\end{array}$ & $\begin{array}{c}42.4(31-51) \\
\mathrm{N}=17\end{array}$ & 0.08 \\
\hline & \multirow[t]{2}{*}{ B } & 2016 & $\begin{array}{c}19.7(17-24)^{\mathrm{a}} \\
\quad \mathrm{N}=13\end{array}$ & $\begin{array}{c}28.0(23-32)^{\mathrm{a}} \\
\quad \mathrm{N}=13\end{array}$ & $\begin{array}{c}39.0(23-50)^{\mathrm{ab}} \\
\mathrm{N}=30\end{array}$ & $\begin{array}{c}50.4(43-56)^{b} \\
\mathrm{~N}=15\end{array}$ & \multirow[t]{2}{*}{$\underline{0.0007}$} \\
\hline & & $\mathrm{P} * *$ & 0.85 & 0.28 & 0.54 & 0.06 & \\
\hline \multirow{6}{*}{ 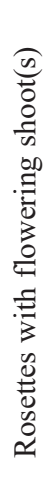 } & \multirow{4}{*}{ A } & 2015 & $\begin{array}{c}6.8(3-9)^{\mathrm{a}} \\
\mathrm{N}=19\end{array}$ & $\begin{array}{c}7.2(3-13)^{\mathrm{a}} \\
\mathrm{N}=20\end{array}$ & $\begin{array}{c}4.3(2-8)^{\mathrm{b}} \\
\mathrm{N}=29\end{array}$ & $\begin{array}{c}4.7( \pm 3.5)^{b} \\
\mathrm{~N}=22\end{array}$ & $\underline{0.005}$ \\
\hline & & 2016 & $\begin{array}{c}6.6(3-9)^{\mathrm{a}} \\
\mathrm{N}=21\end{array}$ & $\begin{array}{c}8.6(5-17)^{\mathrm{ab}} \\
\mathrm{N}=21\end{array}$ & $\begin{array}{c}4.1( \pm 2.6)^{\mathrm{ab}} \\
\mathrm{N}=32\end{array}$ & $\begin{array}{c}4.3( \pm 3.5)^{b} \\
\mathrm{~N}=26\end{array}$ & \multirow[t]{2}{*}{$\underline{0.0003}$} \\
\hline & & $\mathrm{P} * *$ & 0.90 & 0.37 & 0.25 & 0.54 & \\
\hline & & 2015 & $\begin{array}{c}24.4(20-33)^{\mathrm{a}} \\
\quad \mathrm{N}=19\end{array}$ & $\begin{array}{c}26.5(18-36)^{\mathrm{a}} \\
\mathrm{N}=20\end{array}$ & $\begin{array}{c}32.3( \pm 4.5)^{\mathrm{b}} \\
\mathrm{N}=29\end{array}$ & $\begin{array}{c}35.7( \pm 9.8)^{\mathrm{b}} \\
\mathrm{N}=22\end{array}$ & $\underline{0.004}$ \\
\hline & \multirow[t]{2}{*}{ B } & 2016 & $\begin{array}{c}25.5(18-33) \\
\mathrm{N}=21\end{array}$ & $\begin{array}{c}24.3(20-32) \\
\mathrm{N}=21\end{array}$ & $\begin{array}{c}34.4( \pm 4.6) \\
\mathrm{N}=32\end{array}$ & $\begin{array}{c}36.5( \pm 9.3) \\
\mathrm{N}=26\end{array}$ & \multirow[t]{2}{*}{0.06} \\
\hline & & $\mathrm{P} * *$ & 0.93 & 0.41 & 0.24 & 0.87 & \\
\hline
\end{tabular}


permanent plots increased similarly. Moreover, the observed much lower combined share of seedlings and vegetative rosettes of the species in meadow Patches (Fig. 1) might be due to a lack of gaps in the continuous plant cover performing the role of "safe sites for seedling recruitment" in Molinion caeruleae meadows (Kostrakiewicz, 2011; Kostrakiewicz-Gierałt, 2014). The recorded abundant appearance of offsprings in Patches III and IV might be the effect of the occurrence of openings in the plant cover. On the other hand, Franzén (2001) asserted that the established vegetation in dry-mesic seminatural grasslands does not limit recruitment of $F$. vulgaris seedlings.

The performed studies suggest that a dense canopy in abandoned meadows seems to favour individuals creating short, multi-leaved rosettes, while the considerable percentage of bare soil in frequently disturbed grasslands promotes the production of rosettes with scarce, long leaves (Table 2 ). This phenomenon might be an effect of the environmentally mediated size/number 'trade-off' of organs. This fundamental principle of strategy theory in evolutionary ecology assumes that individuals allocate their resources optimally between number and size of organs to maximise fitness (Roff, 1992). To date, the leaf size/number trade-off was observed in trees (e.g. Fonseca et al., 2000; McDonald et al., 2003; Kleiman \& Aarssen, 2007; Yang et al., 2008). The aforementioned authors argued that many small leaves tend to be advantageous in dry, cold, windy, high-altitude and low-nutrient habitats, but that their photosynthetic capacity is usually limited by the stressful environments. In addition, the trade-offs between the size and number was studied in the production of flowers (Sargent et al., 2007; Kettle et al., 2011), fruits (Dombroskie et al., 2016) and seeds (Shipley \& Dion, 1992; Jakobsson \& Eriksson, 2000; Moles et al., 2004).

The performed investigations also showed lack of spatial and temporal variability of the number of flowering shoots (Table 3). Moreover, the recorded similar in consecutive years height of generative shoots, number of

Table 3. The mean (range) number of flowering shoots per rosette, height of flowering shoot, number of cauline leaves and inflorescences per flowering shoot, number of flowers per inflorescence of Filipendula vulgaris Moench in study plots established in meadows (Patch I and II) and calcareous grasslands (Patch III and IV) in the years 2015 and 2016. Explanations as in Table 2

\begin{tabular}{|c|c|c|c|c|c|c|}
\hline \multirow{6}{*}{ 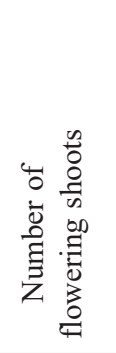 } & \multirow[b]{3}{*}{2015} & \multicolumn{4}{|c|}{ Patch } & \multirow{2}{*}{$\mathbf{P}^{*}$} \\
\hline & & I & II & III & IV & \\
\hline & & $1.0(1-1)$ & $1.1(1-2)$ & $(1-2)$ & $1.1(1-2)$ & 0.25 \\
\hline & \multirow[b]{2}{*}{2016} & $1.0(1-1)$ & $1.4(1-2)$ & $(1-1)$ & $1.1(1-2)$ & \multirow{3}{*}{0.23} \\
\hline & & $\mathrm{N}=21$ & $\mathrm{~N}=21$ & $\mathrm{~N}=32$ & $\mathrm{~N}=26$ & \\
\hline & $\mathrm{P}^{* *}$ & 1.00 & 0.75 & 1.00 & 0.88 & \\
\hline \multirow{4}{*}{ 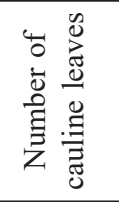 } & \multirow{2}{*}{2015} & $2.6(2-3)^{\mathrm{ab}}$ & $3.5(3-5)^{\mathrm{a}}$ & $2.2(1-4)^{b}$ & $1.2(1-3)^{\mathrm{b}}$ & \multirow{2}{*}{0.008} \\
\hline & & $\mathrm{N}=19$ & $\mathrm{~N}=20$ & $\mathrm{~N}=29$ & $\mathrm{~N}=25$ & \\
\hline & 2016 & $\begin{array}{c}3.1(2-5) \\
\mathrm{N}=21\end{array}$ & $\begin{array}{c}2.9(2-4) \\
\mathrm{N}=25\end{array}$ & $\begin{array}{c}2.8(2-4) \\
\mathrm{N}=32\end{array}$ & $\begin{array}{c}2.9(2-4) \\
\mathrm{N}=29\end{array}$ & \multirow[t]{2}{*}{0.86} \\
\hline & $\mathrm{P}^{* *}$ & 0.30 & 0.08 & 0.60 & $\underline{0.01}$ & \\
\hline \multirow{5}{*}{ 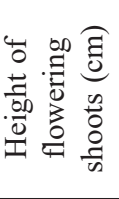 } & & $69.3(59-82)^{\mathrm{a}}$ & $62.9(56-68)^{\mathrm{ab}}$ & $55.0(41-98)^{\mathrm{b}}$ & $60.5(42-74)^{\mathrm{ab}}$ & \multirow{2}{*}{0.001} \\
\hline & 2015 & $\mathrm{~N}=19$ & $\mathrm{~N}=20$ & $\mathrm{~N}=29$ & $\mathrm{~N}=25$ & \\
\hline & \multirow{2}{*}{2016} & $72.3(58-95)^{\mathrm{a}}$ & $65.8(56-72)^{\mathrm{ab}}$ & $58.2(40-106)^{\mathrm{b}}$ & $64.5(40-79)^{\mathrm{ab}}$ & \multirow{3}{*}{0.01} \\
\hline & & $\mathrm{N}=21$ & $\mathrm{~N}=25$ & $\mathrm{~N}=32$ & $\mathrm{~N}=29$ & \\
\hline & $\mathrm{P}^{* *}$ & 0.67 & 0.10 & 0.78 & 0.21 & \\
\hline \multirow{5}{*}{ 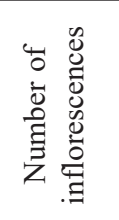 } & 2015 & $1.4(1-2)$ & $1.3(1-2)$ & $1.1(1-2)$ & $1.0(1-1)$ & \multirow{2}{*}{0.22} \\
\hline & 2013 & $\mathrm{~N}=19$ & $\mathrm{~N}=20$ & $\mathrm{~N}=29$ & $\mathrm{~N}=25$ & \\
\hline & \multirow{2}{*}{2016} & $1.6(1-2)^{\mathrm{a}}$ & $1.4(1-3)^{\mathrm{ab}}$ & $1.2(1-2)^{\mathrm{ab}}$ & $(1-1)^{\mathrm{b}}$ & \multirow{3}{*}{0.0008} \\
\hline & & $\mathrm{N}=21$ & $\mathrm{~N}=25$ & $\mathrm{~N}=32$ & $\mathrm{~N}=29$ & \\
\hline & $\mathrm{P} * *$ & 0.49 & 0.85 & 0.76 & 1.00 & \\
\hline \multirow{5}{*}{ 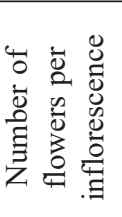 } & 2015 & $62.8(28-97)^{\mathrm{a}}$ & $53.1(15-92)^{\mathrm{ab}}$ & $32.3(6-77)^{\mathrm{b}}$ & $40.4(23-72)^{\mathrm{ab}}$ & \multirow{2}{*}{0.001} \\
\hline & 2013 & $\mathrm{~N}=23$ & $\mathrm{~N}=22$ & $\mathrm{~N}=36$ & $\mathrm{~N}=25$ & \\
\hline & 2016 & $59.0(18-115)^{\mathrm{a}}$ & $66.2(12-86)^{\mathrm{ab}}$ & $41.9(6-83)^{b}$ & $37.8(22-78)^{\mathrm{ab}}$ & \multirow{3}{*}{0.001} \\
\hline & & $\mathrm{N}=28$ & $\mathrm{~N}=28$ & $\mathrm{~N}=32$ & $\mathrm{~N}=29$ & \\
\hline & $\mathrm{P}^{* *}$ & 0.76 & 0.43 & 0.78 & 0.43 & \\
\hline
\end{tabular}


cauline leaves, inflorescences and flowers - decreasing in subsequent study sites - correspond with the observations of van Groenendael (1986), who found that individuals of Plantago lanceolata growing in meadows developed higher flowering shoots with longer inflorescences than those in open dune grasslands. The appearance of high flowering shoots with a considerable number of inflorescences and flowers in the vicinity of tall-growing plants might contribute to an improvement of pollination. This phenomenon was observed in other rosette-forming species inhabiting overgrowing meadows such as Betonica officinalis (Kostrakiewicz-Gierałt, 2015a, 2017a), Serratula tinctoria (Kostrakiewicz-Gierałt \& Bąba, 2014), Succisa pratensis (van der Meer et al., 2014; Kostrakiewicz-Gierałt, 2015b, 2017b). Moreover, the aforementioned species, similarly to $F$. vulgaris, show an increase of number of cauline leaves improving light capture in the neighbourhood of plants of a substantial size (Table 3 ).

\section{Conclusions}

In summary, the present results clearly indicate that sparse and short-statured vegetation established on dry, alkaline ground provides the occurrence of safe sites for the recruitment of new individuals of $F$. vulgaris, leading to an increase in population abundance, as well as favouring the development of rosettes with large leaves. On the other hand, the occurrence of higher neighbouring plants contributes to an increase in the height of generative shoots, as well as a substantial number of cauline leaves, inflorescences and flowers of the species. Considering the relation between morphological traits and content of secondary metabolites observed in many species (Paul et al., 2011; Akhtar et al., 2014; Wahid et al., 2016), it could be concluded that the performed investigations provide a basis for further studies on the impact of habitat conditions and size of the aboveground parts of F. vulgaris on the content of bioactive compounds in plant material.

\section{References}

Akhtar N.F., Aharizad S., Mohammadi S.A., MotallebiAzar A. \& Movafeghi A., 2014, The study of relationship between morphological traits and hypericins content in Hypericum perforatum L.. Technical Journal of Engineering and Applied Sciences 4(2): 45-47.

Allen D., Bilz M., Leaman D.J., Miller R.M., Timoshyna A. \& Window J., 2014, European Red List of Medicinal Plants. Publications Office of the European Union, Luxembourg.

Bączek K., Przybył J.L., Angielczyk M., Kuczerenko A., Pelc, M. \& Węglarz Z., 2010, Accumulation of phe- nolic compounds in leaves and underground organs of dropwort (Filipendula vulgaris L.). 28th International Horticultural Congress "Science and Horticulture for People", Lisboa, Portugal, Aug. 22-27, Abstracts I: 74. Barak P., Jobe B.O., Krueger A.R., Peterson L.A. \& Laird D.A., 1997, Effects of long-term soil acidification due to nitrogen fertilizer inputs in Wisconsin. Plant and Soil 197: 61-69.

Barna M., 2004, Adaptation of european beech (Fagus sylvatica L.) to different ecological conditions: leaf size variation. Polish Journal of Ecology 52(1(1): $35-45$.

Capecka E., Geszprych A., Przybył J.L., Kunicki E., Binder A., Bączek K. \& Węglarz Z., 2012, Accumulation of phenolic compounds in underground organs of dropwort (Filipendula vulgaris Moench). Acta Scientarum Polonorum, Hortorum Cultus 11(4): 101-109.

Cerdà A. \& García-Fayos P., 1997, The influence of slope angle on sediment, water and seed losses on badland landscapes. Geomorphology 18(2): 77-90.

Cheffings C.M., Farrell L. Dines T.D., Jones R.A., Leach S.J., McKean D.R., Pearman D.A., Preston C.D., Rumsey F.J. \& Taylor I., 2005, The Vascular Plant Red Data List for Great Britain. Joint Nature Conservation Committee, Peterborough.

Clapham A.R., Tutin T.G. \& Moore D.M., 1987, Flora of the British Isles. Cambridge University Press, Cambridge.

Curtis T.G.F. \& McGough H.N., 1988, The Irish Red Data Book. 1 Vascular Plants. Wildlife Service, Dublin, Ireland.

Dombroskie S.L., Tracey A.J. \& Aarssen LW., 2016, Leafing intensity and the fruit size/number trade-off in woody angiosperms. J. Ecol. 104(6): 1759-1767.

Dubiel E., Stachurska A. \& Gawroński S., 1999, Nieleśne zbiorowiska roślinne Magurskiego Parku Narodowego (Beskid Niski) [Non-forest communities of the Magura National Park (Beskid Niski Mts.)]. Zeszyty Naukowe Uniwersytetu Jagiellońskiego, Prace Botaniczne 33: $1-60$.

Fonseca C.R., Overton J.M., Collins B. \& Westoby M., 2000, Shifts in trait-combinations along rainfall and phosphorus gradients. J. Ecol. 88: 964-977.

Franzén D., 2001, The role of species richness for recruitment in a seminatural grassland. Oikos 95(3): 409-415.

García-Fayos P., Bochet E. \& Cerdà A., 2010, Seed removal susceptibility through soil erosion shapes vegetation composition. Plant and Soil 334(1): 289-297.

García-Fayos P., García-Ventoso B. \& Cerdà A., 2000, Limitations to plant establishment on eroded slopes in southeastern Spain. Journal of Vegetation Science 11(1): 77-86.

García-Fayos P., Recatalá T.M., Cerdá A. \& Calvo A., 1995 , Seed population dynamics on badland slopes in 
southeastern Spain. Journal of Vegetation Science 6(5): 691-696.

Goulding K.W.T., 2016, Soil acidification and the importance of liming agricultural soils with particular reference to the United Kingdom. Soil Use and Management 32: 390-399.

Gross N., Robson T.M., Lavorel S., Albert C., Le Bagousse-Pinguet Y. \& Guillemin R., 2008, Plant response traits mediate the effects of subalpine grasslands on soil moisture. New Phytologist 180(3): 652662.

Guo J.H., Liu X.J., Zhang Y., Shen J.L., Han W.X., Zhang W.F., Christie K., Goulding W.T., Vitousek P.M. \& Zhang F.S., 2010, Significant acidification in major Chinese croplands. Science 327: 1008-1010.

Hampe A., 2005, Fecundity limits in Frangula alnus (Rhamnaceae) relict populations at the species' southern range margin. Oecologia 14(3): 377-386.

Harrison C., 1981, Recovery of lowland grassland and heathland in southern England from disturbance by seasonal trampling. Biological Conservation 19(2): 119-130.

Hegland S.J., Van Leeuwen M. \& Oostermeijer J.G.B., 2001, Population structure of Salvia pratensis in relation to vegetation and management of Dutch dry floodplain grasslands. Journal of Applied Ecology 38(6): 1277-1289.

Hesp P., Schmutz P., Martinez M.L., Driskell L., Orgera R., Renken K., Revelo N.A.R. \& Orocio O.A.J., 2010, The effect on coastal vegetation of trampling on a parabolic dune. Aeolian Research 2(2-3): 105-111.

Jakobsson A. \& Eriksson O.A., 2000, Comparative study of seed number, seed size, seedling size, and recruitment in grassland plants. Oikos 88: 494-502.

Jiao J.Y., Han L.Y., Jia Y.F., Lei D., Wang N. \& Li L.Y., 2013, Seed morphology characteristics in relation to seed loss by water erosion in the Loess Plateau. Springerplus 2(1): Article Number: S9.

Kahmen S. \& Poshlod P., 2000, Population size, plant performance, and genetic variation in the rare plant Arnica montana L. in the Rhön, Germany. Basic and Applied Ecology 1: 43-51.

Katanic J., Mihailovic V., Stankovic N. Boroja T., Mladenovic M., Solujic S., Stankovic M.S. \& Vrvic M.M., 2015, Dropwort (Filipendula hexapetala Gilib.): potential role as antioxidant and antimicrobial agent. Experimental and Clinical Sciences Journal 14: 1-20.

Kettle C.J., Maycock C.R., Ghazoul J., Hollingsworth P.M., Khoo E., Sukri R.S.H. \& Burslem D.F.R.P., 2011, Ecological implications of a flower size/number tradeoff in tropical forest trees. Plos One 6(2): Article Number: e16111.

Kleiman D. \& Aarssen L.W., 2007, The leaf size/number trade-off in trees. J. Ecol. 95(2): 376-382.
Klimešová J. \& Klimeš L., 2006, Clo-Pla 3Database of clonal growth of plants from Central Europe. Available from: http://clopla.butbn.cas.cz/

Kondracki J., 2000, Geografia regionalna Polski [Regional Geography of Poland], PWN, Warsaw.

Kostrakiewicz K., 2011, The effect of gaps size on colonization process in Molinietum caeruleae meadows with different habitat conditions. Polish Journal of Ecology 59(4): $677-686$.

Kostrakiewicz-Gierałt K. \& Bąba W., 2014, The influence of standing vegetation height on the reproductive allocation in populations of Serratula tinctoria L. (Asteraceae). Polish Journal of Ecology 62: 89-99.

Kostrakiewicz-Gierałt, K., 2014, The effects of successional stage and size of gaps on recruitment of clonal plant in overgrowing Molinietum caeruleae meadows. Acta Agrobotanica 67(4): 87-98.

Kostrakiewicz-Gierałt, K., 2015a, The impact of different habitat conditions on the variability of wild populations of a medicinal plant Betonica officinalis L., Ekologia Balkanica 7(1): 51-61.

Kostrakiewicz-Gierałt K., 2015b, The variability of Succisa pratensis Moench individuals and ramet clust ers in abandoned Molinietum caeruleae meadows. Ekológia (Bratislava) 34(3): 216-225.

Kostrakiewicz-Gierałt K., 2017a, The impact of habitat conditions on the performance of generative ramet clusters of high medicinal value, rare species Betonica officinalis L.. International Journal of Conservation Science 8(1): 89-104.

Kostrakiewicz-Gierałt K., 2017b, Population traits of the rare plant species Succisa pratensis Moench in meadow overgrowing. Archives of Biological Sciences 69(2): 323-33.

Kulik M., 2014, Changes in biodiversity and species composition of Molinia meadow depending to use method. Polish Journal of Environmental Studies 23(3): 773782.

Lempiäinen T., 1982, Morphological and chemical variation among Eurasian populations of Filipendula vulgaris (Rosaceae). Annales Botanici Fennici 19(3): 127-146.

Lempiäinen T., 1978, The effect of cultivation and fertilizers on Filipendula vulgaris Moench, especially on its tuberous roots. Acta Botanica Fennica 107: 1-22.

Maksimović Z., Petrović S., Pavlović M., Kovačević N. \& Kukić J., 2007, Antioxidant activity of Filipendula hexapetala flowers. Fitoterapia 78: 265-267.

McDonald P.G., Fonseca C.R., Overton J.M. \& Westoby M., 2003, Leaf-size divergence along rainfall and soil-nutrient gradients: is the method of size reduction common among clades? Functional Ecology 17: 50-57.

Medwecka-Kornaś A., Kornaś J. \& Pawłowski B., 1966, Survey of the most important plant associations in Po- 
land, [in:] W. Szafer (ed,), The Vegetation of Poland. Pergamon Press, Oxford: 294-509.

Moles A.T., Falster D.S., Leishman M.R. \& Westoby M., 2004, Small-seeded species produce more seeds per square meter of canopy per year, but not per individual per lifetime. J. Ecol. 92: 384-396.

Morozowska M., 2000, Spatial structure of cowslip, Primula veris (L.) populations from natural localities of Wielkopolska region (Poland), [in:] P. Elias (ed.), Plant Population Biology, VI. SEKOS, Bratislava-Nitra: 26-32.

Moser D., Gygax A., Bäumler B., Wyler N. \& Palese R., 2002, Liste Rouge des fougères et plantes à fleurs menaces de Suisse. Office fédéral de l'environnement, des forêts et du paysage, Berne, Switzerland.

Paul S., Naqvi A.A., Gupta M.M. \& Khanuja S.P.S., 2011, Relationship between morphological traits and secondary metabolites in Artemisia annua L. by using correlation and path analysis. Electronic Journal of Plant Breeding 2(3): 466-472.

Pavlovic M., Petrovic S., Ristic M., Maksimovic Z. \& Kovacevic N. 2007, Essential oil of Filipendula hexapetala. Chemistry of Natural Compounds 43(2): 228 229.

Pickering C.M. \& Growcock A.J., 2009, Impacts of experimental trampling on tall alpine herbfields and subalpine grasslands in the Australian Alps. Journal of Environmental Management 91(2): 532-540.

Preacher K.J., 2001, Calculation for the chi-square test: An interactive calculation tool for chi-square tests of goodness of fit and independence [Computer software]. Available from: http://quantpsy.org.

Roff D.A., 1992, The evolution of life histories: theory and analysis. Chapman and Hall, New York, USA.

Samardžić S., Tomić M., Pecikozab U., StepanovićPetrovićb R. \& Maksimović Z., 2016, Antihyperalgesic activity of Filipendula ulmaria (L.) Maxim. and Filipendula vulgaris Moench in a rat model of inflammation. Journal of Ethnopharmacology 193(4): 652-656.

Sargent R.D., Goodwillie C., Kalisz S. \& Rees R.H., 2007, Phylogenetic evidence for a flower size and number trade-off. American Journal of Botany 94(12): 2059-2062.

Shilova I.V. \& Suslov N,I., 2015, Nootropic effect of Meadowsweet (Filipendula vulgaris) extract. Bulletin of Experimental Biology and Medicine 158(5): 659663.

Shilova I.V., Suslov N.I. \& Amelchenko V.P., 2015, Nootropic effects of Filipendula vulgaris Moench water extract fractions. Bulletin of Experimental Biology and Medicine 159(3): 376-379.
Shipley B. \& Dion J., 1992, The allometry of seed production in herbaceous angiosperms. American Naturalist 139: 467-483.

Skrzypek E., Repka P., Stachurska-Swakoń A., BarabaszKrasny B, \& Możdżeń K., 2015, Allelopathic effect of aqueous extracts from the leaves of peppermint (Mentha $\times$ piperita L.) on selected physiological processes of common sunflower (Helianthus annuus L.). Notulae Botanicae Horti Agrobotanici Cluj-Napoca 43(2): 335-342.

Stroh P.A., Leach S.J., August T.A., Walker K.J., Pearman D.A., Rumsey F.J., Harrower C.A., Fay M.F., Martin J.P., Pankhurst T., Preston C.D. \& Taylor I., A., 2014, Vascular Plant Red List for England. Botanical Society of Britain and Ireland, Bristol, UK.

Towpasz K. \& Stachurska-Swakoń A., 2012, Seslerio uliginosae-Scorzoneretum purpureae (Festuco-Brometea class) in the Nida Basin (Małopolska Upland) after 90 years. Acta Societatis Botanicorum Poloniae 81(3): 167-173.

Towpasz K. \& Stachurska-Swakoń, A., 2009, Występowanie Sesleria uliginosa (Poaceae) w zbiorowiskach z rzędu Caricetalia davallianae na obszarze Niecki Nidziańskiej (Wyżyna Małopolska) [Occurrence of Sesleria uliginosa (Poaceae) in the communities of the Caricetalia davallianae order in the Nida Basin territory (Małopolska Upland)]. Fragm. Flor. Geobot. Polonica 16(2): 305-316.

Towpasz K. \& Stachurska-Swakoń A., 2011, Występowanie Sesleria uliginosa (Poaceae) w murawach kserotemicznych (Festuco-Brometea) na terenie Niecki Nidziańskiej (Wyżyna Małopolska) [Occurrence of Sesleria uliginosa (Poaceae) in the xerothermic grasslands (Festuco-Brometea) in the Nida Basin territory (Małopolska Upland)]. Fragm. Flor. Geobot. Polonica 18(2): 321-330.

Van der Meer S., Dahlgren J.P., Milden M. \& Ehrlen J., 2014, Differential effects of abandonment on the demography of the grassland perennial Succisa pratensis. Population Ecology 56(1): 151-160.

Van Duren I.C., Strykstra R.J., Grootjans A.P., Heerdt G.N.J. \& Pegtel D.M., 1998, A multidisciplinary evaluation of restoration measures in a degraded CirsioMolinietum fen meadow. Applied Vegetation Science 1: 115-130.

Van Groenendael J.M., 1986, Life history characteristics of two ecotypes of Plantago lanceolata L. Acta Boanica Neerlandica 35(2): 71-86.

Wahid N., Chkichekh A. \& Bakry M., 2016, Morphological traits and essential oil yield variation of three $M y r-$ tus communis L. populations: implication for domestication. Direct Research Journal of Agricultural and Food Science 4(8): 199-207. 
Weidema I.R., Magnussen L.S. \& Philipp M., 2000, Gene flow and mode of pollination in a dry grassland species, Filipendula vulgaris (Rosaceae). Heredity 84(3): 311-320.

Yang D., Li G. \& Sun S., 2008, The generality of leaf size versus number trade-off in temperate woody species. Annals of Botany 102(4): 623-629.

Zając M. \& Zając A., 2009, Elementy geograficzne rodzimej flory Polski [The geographical elements of native flora of Poland]. Institute of Botany, Jagiellonian University, Kraków, Poland.
Zając T., Oleksy A., Stokłosa A. \& Klimek-Kopyra A., 2011, Comparison of morphological traits, productivity and canopy architecture of winter oilseed rape (Brassica napus L.) and white mustard (Sinapis alba L.). Journal of Applied Botany and Food Quality 84(2): 183-191.

Zelnik I. \& Carni A., 2008, Wet meadows of the alliance Molinion and their environmental gradients in Slovenia. Biologia 63(2): 187-196. 